\title{
熱力学的効果を考慮した銀めっき材料のキャビテーション壊食*
}

\author{
服部 修次 ${ }^{* 1}$, 樽谷 佳祐 ${ }^{* 2}$, 籠谷 勇 $^{* 2}$, 菊田 研吾 ${ }^{* 3}$, 都丸 裕司 ${ }^{* 4}$
}

\section{Cavitation Erosion of Silver Plated Coating Considering Thermodynamic Effect}

\author{
Shuji HATTORI"1 ${ }^{*}$, Keisuke TARUYA, Isamu KOMORIYA, Kengo KIKUTA \\ and Hiroshi TOMARU \\ ${ }^{* 1}$ Graduate School of Engineering, University of Fukui, \\ 3-9-1 Bunkyo, Fukui-shi, Fukui, 910-8507 Japan
}

\begin{abstract}
Cavitation often occurs in inducer pumps of space rockets. Silver plated coating on the inducer liner faces the damage of cavitation. In this study, we carried out cavitation erosion tests using silver plated coatings with different thermodynamic parameter at a constant cavitation number. Then we carried out cavitation erosion tests using some liquid with the same thermodynamic parameter and cavitation number as liquid oxygen condition. Thermodynamic parameter $\Sigma$ proposed by Brennen was used as a thermodynamic parameter. The fluids used for the cavitation erosion tests were water, ethanol and hexane. We discussed the relation between thermodynamic parameter and mass loss rate, and the relation between acoustic impedance and mass loss rate.
\end{abstract}

Key Words : Cavitation, Erosion, Inducer, Thermodynamic Parameter, Cavitation Number

\section{1. 緒言}

キャビテーション壊食は，気泡崩壊時の衝撃力が材料表面に繰返し作用して材料表面が塑性変形し，き裂 が発生, 進展して起こる一種の疲労破壊現象である。ポンプやプラント配管, 舶用プロペラなど液体と接す る部材で生じ, 機器の性能や寿命低下につながる問題となっている. ロケット用ターボポンプのインデュー サでは, キャビテーションが発生することがよく知られている(1)(3). 上條ら ${ }^{(1)}$ は, 入口流量係数の変更と昇圧 を下げる設計を行ったインデューサにより逆流キャビテーションの発生が抑制され，旋回失速現象が抑制さ れることを報告している，山田ら (2)は，ポンプ内部のキャビテーションに起因する事故例や不安定振動など を報告している.内海ら (3) はロケット用インデューサの羽根とキャビティ形状との関係の解析法を提案して いる. ロケット用ターボポンプのケーシングとインデューサとのクリアランス部には, 高速回転する羽根車 と接触しても摩擦面を高温にせず，また接触時の損傷を軽減するために銀めっき等の軟質材料が使用されて いる(4),(5).

服部ら ${ }^{(6)}$ は，銀めっき施工後，熱処理なしで実機と同様に表面加工した試験片を用いて，脱イオン水中，液 体窒素中, エタノール中で振動試験片法によるキャビテーション壊食試験を行い, 壊食挙動に及ぼす試験液 や試験温度の影響について検討した. その結果, 脱イオン水中では微小な気泡群が下方へすじ状に発生して 速く壊食するのに対し，液体窒素中では水中に比べて大きい気泡が沸き出すように多数発生するが，ほとん ど壊食しないことを見出した，液体窒素中でキャビテーション壊食が生じなかった原因は，振動キャビテー ション試験の際に生じる運動エネルギーが流体中に熱エネルギーとして伝わることにより, 液体窒素の温度 が上がり, 液体窒素の飽和蒸気圧が上昇したために, 試験面周囲の液体が大気圧になっても気体のままで崩 壊しなかったことによると考えられるが，この点については未検討である.

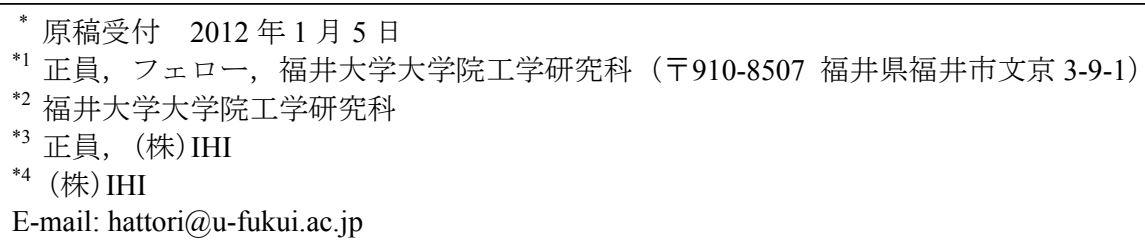


一方 Brennen ${ }^{(7)}$ は, 流れ中の単一蒸気泡の熱力学により, 熱物性のみを抽出した熱力学的パラメータ 出し, 水素, 酸素, 窒素, 水, メタン, フロンの $\Sigma$ と液温(流体の三重点 $\mathrm{T}_{\mathrm{t}}$ と臨界点 $\mathrm{T}_{\mathrm{c}}$ で無次元化)の関係に

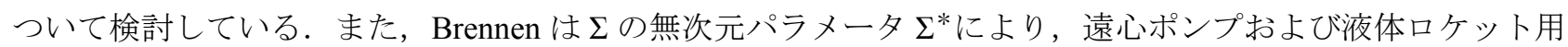

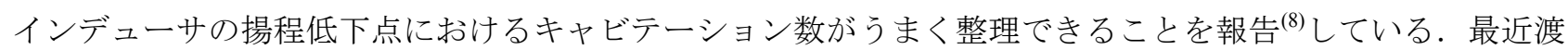
邊ら ${ }^{(9)}$ は, キャビテーションの熱力学的効果とその理論解析について解説している. しかし, これらの研究 はキャビテーションの発生に及ぼす熱力学的効果を検討したもので, 壊食挙動についてはほとんど明らかに なっていない.

本研究では, キャビテーション数をほぼ一定にして熱力学的パラメータを変化させたキャビテーション壊 食試験を行い, 熱力学的効果が壊食にどのように影響するか検討した. 具体的には, キャビテーション数が ほぼ等しくなるように試験圧力を設定し, 脱イオン水とエタノールを使用して異なる数種類の液温で試験を 行い, キャビテーション壊食速度と熱力学的パラメータの関係について検討した. また, 実機で使用されて いる $0.3 \mathrm{MPa}, 90 \mathrm{~K}$ の液体酸素 $(\mathrm{LOX})$ の熱力学的パラメータ，キャビテーション数と同等になるように液温と 圧力を設定した脱イオン水中，エタノール中，ヘキサン中で試験を行い，壊食速度に及ぼす音響インピーダ ンスの影響について検討した.

\section{2. 試験材料及び試験方法}

試験片は，図 1 に示すように直径 $16 \mathrm{~mm}$ の SUS304 製の振動チップ端面に銀めっきを施したものである.

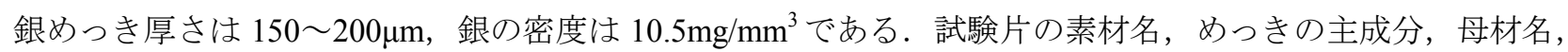
熱処理条件, ビッカース硬さ，表面仕上げを表 1 に示す．熱処理は施しておらず，ビッカース硬さ(HV0.2) は 72.5 である．表面仕上げは製品と同等である。

キャビテーション壞食試験は ASTM G32-03 に規定されている磁わい振動装置(共振周波数 $19.5 \mathrm{kHz}$ )を用い て振動試験片法で行った。0.6MPa まで加圧可能な試験槽(有)宮下製作所製)とマントルヒーター(森)AS ONE 製 HB-1000T)を用いて試験液の温度と圧力を調節して試験を行った. 試験装置の概略図と概観写真をそれぞれ図 2(a), (b)に示す. 温度は, マントルヒーターに温度調節器(侏)AS ONE 製 TC-2000) を接続して調節した. 設定 温度で加熱は停止するが, 加熱が停止した後もキャビテーションによって液温が上昇するため, 加熱が停止し

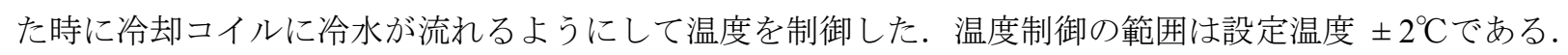
圧力は，密閉した試験槽内にコンプレッサーを用いて空気を送り込むことにより設定した。壊食試験は， 振動子の先端に試験片を取付け, 試験液を所定の圧力に加圧後, 設定温度に加熱して開始した. 試験片先端 の peak-to-peak 振幅は $50 \mu \mathrm{m}$ 一定とした.

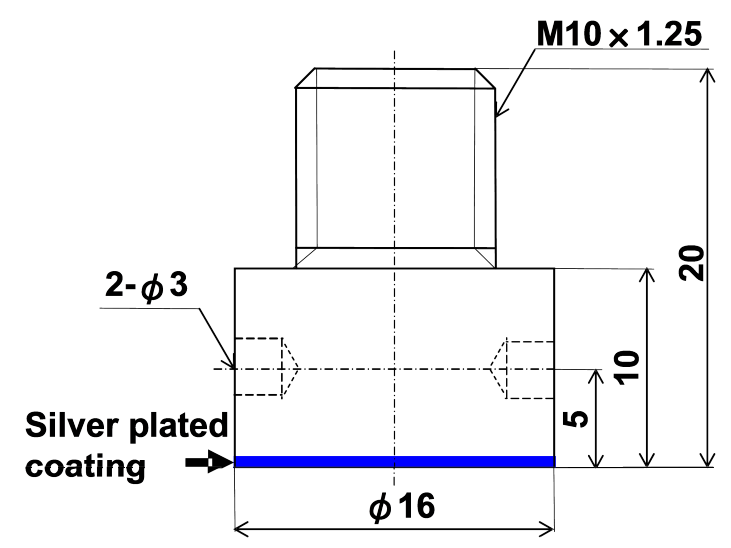

Fig.1 Dimension of specimen

Table 1 Condition of silver plated coating

\begin{tabular}{|c|c|c|c|c|c|}
\hline Designation & Coating metal & Base metal & Heat treatment & HV0.2 & Surface finish \\
\hline $\mathrm{C} 1$ & $\mathrm{Ag}$ & SUS304 & None & 72.5 & Same as the product \\
\hline
\end{tabular}




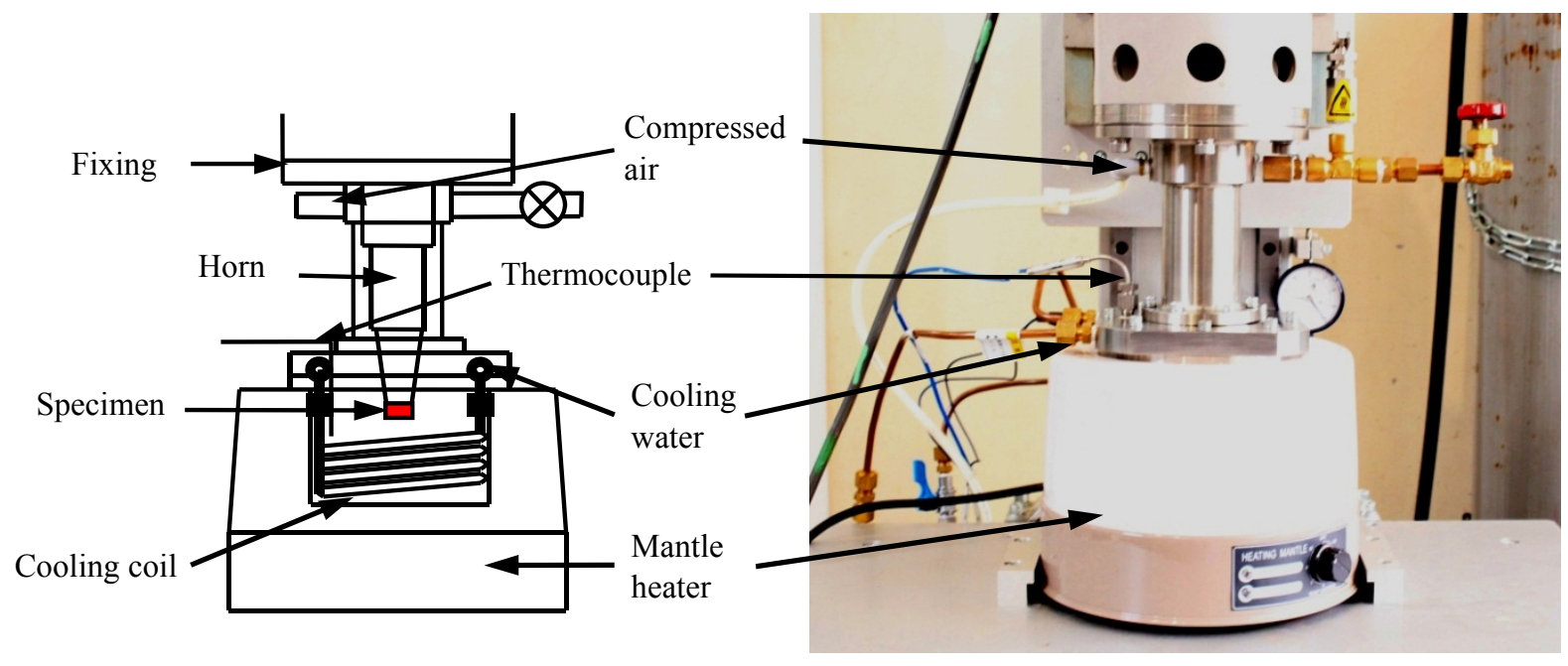

(a) Schematic drawing

(b) Set up photograph

Fig.2 Test apparatus

壊食による質量減少量は，精密天秤(感度 $0.01 \mathrm{mg}$ )で測定した。壊食面の形状は非接触表面形状測定システ ム(侏キーエンス製 LMS-3D : 分解能 $0.1 \mu \mathrm{m}$ ，測定間隔 $2.0 \mu \mathrm{m}$ )で測定した。硬さ試験にはショア硬さ計を使 用し，銀めっき試験片の温度変化させたときの硬さを測定した．試験片の加熱は，硬さ計の台の上にシリコ ンラバーヒーターを設置して温度調節器(侏AS ONE 製 TC-2000)を接続して一定温度で行った.

\section{3. 試験結果及び考察}

\section{$3 \cdot 1 \quad 298 \mathrm{~K} ， 0.1 \mathrm{MPa}$ の脱イオン水を基準にしたキャビテーション壊食試験}

本試験では, 熱力学的効果が壊食速度に及ぼす影響を検討するために熱力学的パラメータが異なる数種類 の液温で試験を行った． 熱力学的効果の大きさを表すパラメータには, Brennen ${ }^{(7)}$ が提案している熱力学的パ

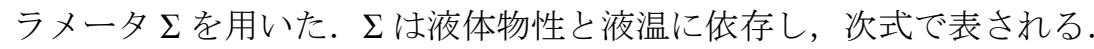

$$
\Sigma\left(T_{\infty}\right)=\left(\rho_{v} L\right) /\left(\rho_{l} c_{p l} T_{\infty} \alpha_{l}^{1 / 2}\right)
$$

$T_{\infty}$ は試験温度, $\rho_{v}$ は気体の密度, $\rho_{l}$ は液体の密度, $L$ は蒸発潜熱, $c_{p l}$ は定圧比熱, $\alpha_{l}$ は液体の熱拡散率である.

図 3 は，試験液の三重点から臨界点までの熱力学的パラメータ $\Sigma$ の変化を示した図である ${ }^{(10)}$. 各プロット 点は，(1)式を用いて計算した点である．いずれの試験液も温度が上昇するに伴って $の$ 值は大きくなる．本 試験では，比較的試験の容易な脱イオン水とエタノールを使用して壊食試験を行った。

表 2 は, 本研究で用いた試験液の種類, 試験温度, 熱力学的パラメータ $\Sigma$, 試験圧力, 飽和蒸気圧, 液体 の密度, キャビテーション数を示したものである. 試験条件は, $90 \mathrm{~K} の \mathrm{LOX}$ 中 $(\Sigma=14500)$ 及び, 磁わい振動 装置による壊食試験結果が豊富に存在する $298 \mathrm{~K}\left(25^{\circ} \mathrm{C}\right)$ の脱イオン水中 $(\Sigma=7)$ の 2 つを基本条件とした. 脱イオ ン水中では， $\Sigma=7$ となる $298 \mathrm{~K}\left(25^{\circ} \mathrm{C}\right)$ 及び $\Sigma=14500$ となる $401 \mathrm{~K}\left(128^{\circ} \mathrm{C}\right)$ で試験を行った。 また， $\Sigma=7$ と 14500 の間を対数的にほぼ等間隔になるように $\Sigma=100$ と 1028 を設定し，この $\Sigma$ に対応する $324 \mathrm{~K}\left(51^{\circ} \mathrm{C}\right), 352 \mathrm{~K}\left(79^{\circ} \mathrm{C}\right)$ でも試験を行った. エタノール中では, $\Sigma=14500$ に対応寸る $354 \mathrm{~K}$ 及び $\Sigma=225,1950$ に対応寸る $303 \mathrm{~K}\left(30^{\circ} \mathrm{C}\right)$, $327 \mathrm{~K}\left(54^{\circ} \mathrm{C}\right)$ で試験を行った。試験圧力は, 基本条件の 1 つである大気圧, $298 \mathrm{~K}\left(25^{\circ} \mathrm{C}\right)$ の脱イオン水中のキャ ビテーション数 51.8 と一致するように設定した. キャビテーション数は以下の式で定義した.

$$
\sigma=\left(P-P_{V}\right) /\left(1 / 2 \rho_{l} v^{2}\right)
$$

$P$ は試験圧力， $P_{V}$ は飽和蒸気圧， $v$ は流速である．振動法で流速を測定することは難しいが，流速は試験端 


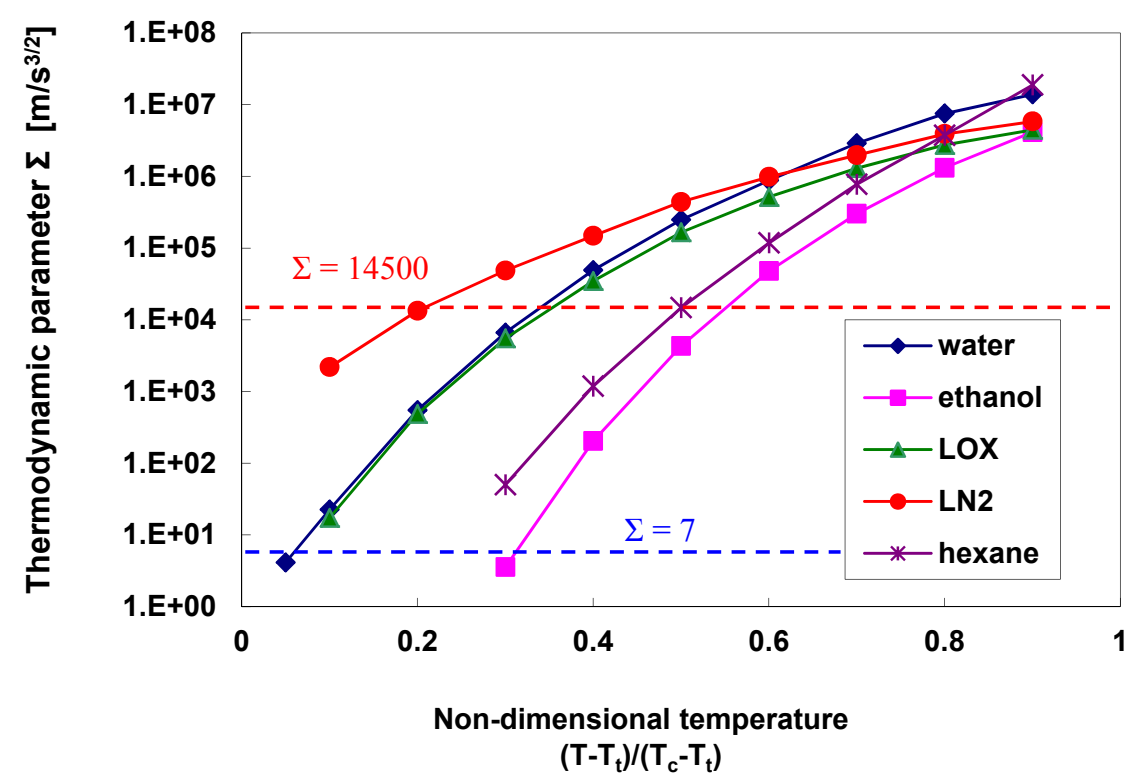

Fig.3 Thermodynamic parameter $\Sigma$

Table 2 Test conditions based on deionized water at $298 \mathrm{~K}$

\begin{tabular}{|c|c|c|c|c|c|c|}
\hline Test liquid & $\begin{array}{c}\text { Temperature } \\
{[\mathrm{K}]}\end{array}$ & $\begin{array}{c}\text { Thermodynamic } \\
\text { parameter } \\
\Sigma\end{array}$ & $\begin{array}{c}\text { Test } \\
\text { pressure } \\
{[\mathrm{MPa}]}\end{array}$ & $\begin{array}{c}\text { Saturated vapor } \\
\text { pressure } \\
{[\mathrm{MPa}]}\end{array}$ & $\begin{array}{c}\text { Liquid } \\
\text { density } \\
{\left[\mathrm{kg} / \mathrm{m}^{3}\right]}\end{array}$ & $\begin{array}{c}\text { Cavitation } \\
\text { number }\end{array}$ \\
\hline $\begin{array}{c}\text { Liquid } \\
\text { oxygen }\end{array}$ & 90 & 14500 & - & 0.0994 & 1142 & - \\
\hline $\begin{array}{c}\text { Deionized } \\
\text { water }\end{array}$ & 298 & 7 & 0.101 & 0.0031 & 997 & 51.8 \\
\hline $\begin{array}{c}\text { Deionized } \\
\text { water }\end{array}$ & 324 & 100 & 0.110 & 0.0129 & 988 & 51.8 \\
\hline $\begin{array}{c}\text { Deionized } \\
\text { water }\end{array}$ & 352 & 1028 & 0.141 & 0.0452 & 972 & 51.8 \\
\hline $\begin{array}{c}\text { Deionized } \\
\text { water }\end{array}$ & 401 & 14500 & 0.345 & 0.2530 & 937 & 51.8 \\
\hline Ethanol & 303 & 225 & 0.101 & 0.0105 & 781 & 61.2 \\
\hline Ethanol & 327 & 1950 & 0.110 & 0.0356 & 760 & 51.8 \\
\hline Ethanol & 354 & 14500 & 0.184 & 0.1120 & 732 & 51.8 \\
\hline Ethanol & 243 & $(0.9)$ & 0.101 & 0.0002 & 831 & 63.9 \\
\hline
\end{tabular}

面の振動振幅と振動速度(共振周波数)から求めた $\left(50 \times 10^{-6} \mathrm{~m} \times 2 \times 19500=1.95 \mathrm{~m} / \mathrm{s}\right)$. また, いずれのキャビテーシ ヨン条件下でも流速は等しいと考えると，試験圧力の算出式は以下の式で表される.

$$
P_{e x}=\left(\rho_{l \_x} / \rho_{l}\right)\left(P-P_{V}\right)+P_{V_{-} e x}
$$

ex が表記されているものは，実施する試験条件の数值であり，表記されていないものは，基準とする試験条 件における数值である． $243 \mathrm{~K} ， 303 \mathrm{~K}$ のエタノール中における試験では，キャビテーション数を一致させる

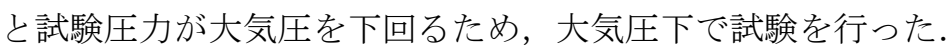

キャビテーション壊食試験を行う前に，試験温度の変化に伴って銀めっき材料の強度が変化するかどうか を確かめるため，母材の SUS304 と銀めっき材の 303K～403K の硬さ測定を行った. SUS304 は耐熱材料であ り, 303K〜 403K では硬さは変化しないが, 念のため硬さ測定を行った. 硬さ測定の結果を図 4 に示寸. SUS304 のショア硬さは $303 \mathrm{~K}$ で 35.5 であり, この值はビッカース硬さでは 236 に相当 ${ }^{(1)} し$, SUS304 の值としてはほ 


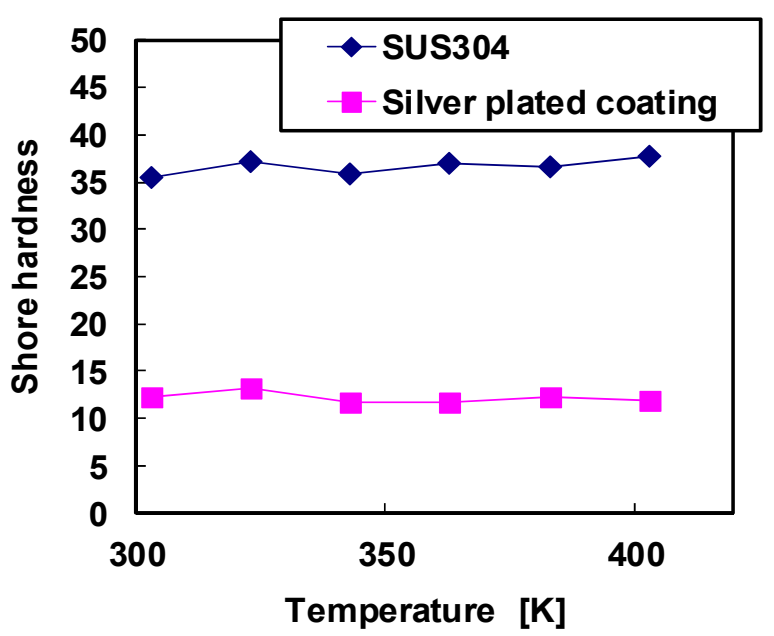

Fig.4 Relation between Shore hardness and temperature

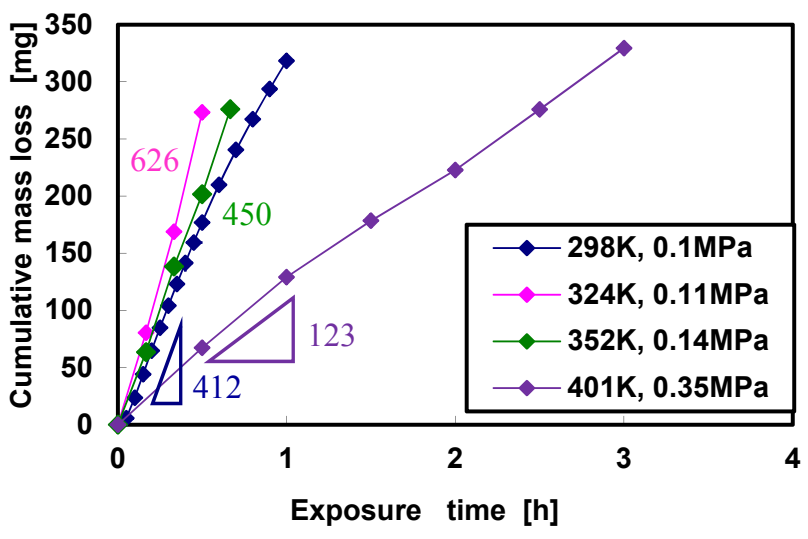

Fig. 5 Mass loss curves of deionized water

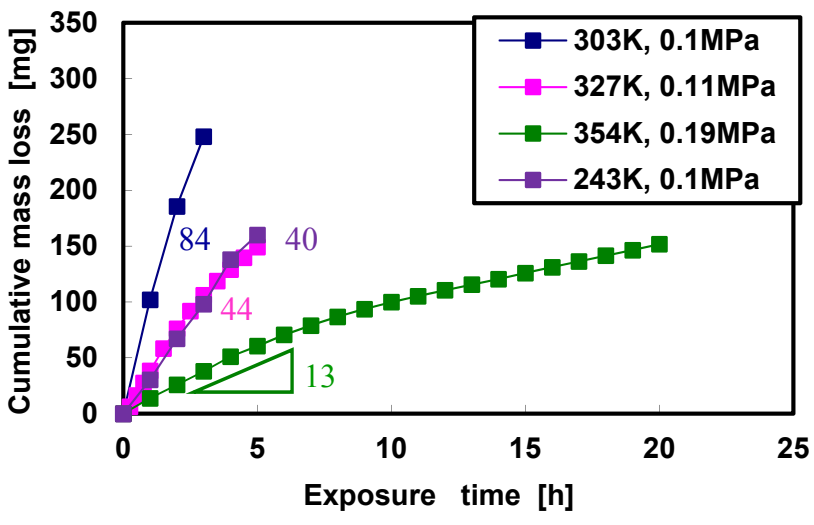

Fig. 6 Mass loss curves of ethanol

ぼ妥当であると考えられる. 温度を $20 \mathrm{~K}$ ずつ上昇させても, ショア硬さは 35 3 9 の間で, 温度が変化して もショア硬さはほとんど変化していない，銀めっき材料の硬さは $303 \mathrm{~K}$ で 12.3 であり，この值はビッカース

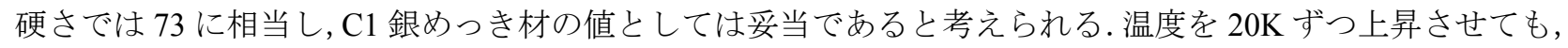
ショア硬さは $11 〜 13$ の間で, 温度が変化してもショア硬さはほとんど変化していない. そのため, 303K〜 403K のキャビテーション壊食試験では材料特性の温度依存性を考える必要はなく, 液体特性の温度依存性のみ考 えれば十分である.

図 5 は脱イオン水の各種条件下での累積質量減少量曲線である.脱イオン水の空気飽和度は $92.9 \%$ ある. いずれの曲線も明瞭な潜伏期は現れておらず，最大速度期は試験直後に現れている．めっき材は軟らかいた め，潜伏期が極めて短いと考えられる．298K での試験は，試験開始直後からほぼ直線的に壊食が進み，試

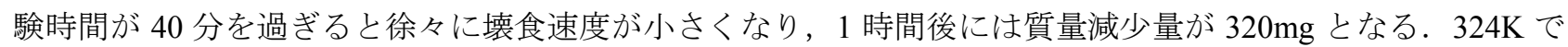
の試験もほぼ直線的に壊食が進んでおり，298K での試験より壊食速度が大きい. 352K での試験もほぼ直線 的に壊食が進んでおり，298K での試験より壊食速度が大きいが，324K での試験より壊食速度は逆に小さく

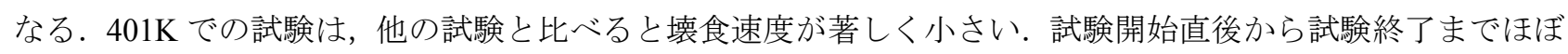
直線的に壊食が進むが，298K での試験と同じ壊食量に達するまでに約 3 倍の時間を要する. 図中の数值は, 各曲線の最大速度期の勾配である。

図 6 はエタノール中での質量減少量の曲線である.エタノール中での試験においても明瞭な潜伏期は現れ ておらず, 最大速度期が試験直後に現れている. 脱イオン水中での試験と比べると壊食速度が小さく, 試験

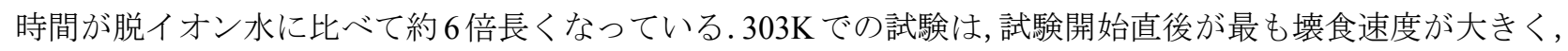


徐々に壊食速度が小さくなっている. 327K での試験は，303K での試験より壊食速度が小さく，303K での試 験と同様に試験開始直後が最も壊食速度が大きく, 徐々に壊食速度が小さくなっている．354Kでの試験は， $327 \mathrm{~K}$ での試験より壊食速度が小さく, 試験開始 5 時間までほぼ直線的に壞食が進むが，試験開始 5 時間以降 は壊食速度が徐々に小さくなり, 10 時間後には約 $5 \mathrm{mg} / \mathrm{h}$ となっている. その後, 壊食速度はほとんど变化せ

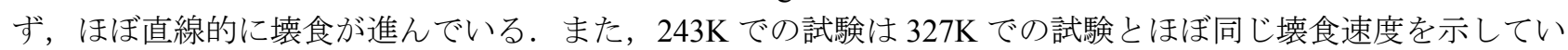
る.

図 7 は，図 5, 図 6 の曲線の最大速度期の壊食速度と熱力学的効果の関係を表したものである。一般に揚 程低下点におけるキャビテーション数は, 熱力学的パラメータ $\Sigma$ が増加しても一定值のままである ${ }^{(8)}$ が, さ らに $\Sigma$ が増加するとキャビテーション数は低下することが報告されている. Gross ら ${ }^{(12)}$ は, 液体酸素中でキ ヤビテーション試験を行い $\Sigma=1.5 \sim 7.0 \times 10^{4} \mathrm{~m} / \mathrm{s}^{3 / 2}$ で, Yoshida らは液体窒素中の $\Sigma=4.7 \times 10^{4} \mathrm{~m} / \mathrm{s}^{3 / 2(13)}$ 及び $1.3 \sim$ $8.1 \times 10^{4} \mathrm{~m} / \mathrm{s}^{3 / 2(14)}$ で, 菊田ら ${ }^{(15)}$ は液体窒素中の $\Sigma=3.8 \times 10^{4} \mathrm{~m} / \mathrm{s}^{3 / 2}$ 及び $1.3 \times 10^{4} \mathrm{~m} / \mathrm{s}^{3 / 2}$ で, Franc ら ${ }^{(16)}$ は $\mathrm{R} 114$ 中の $\Sigma=2.4$

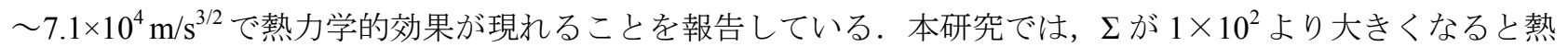

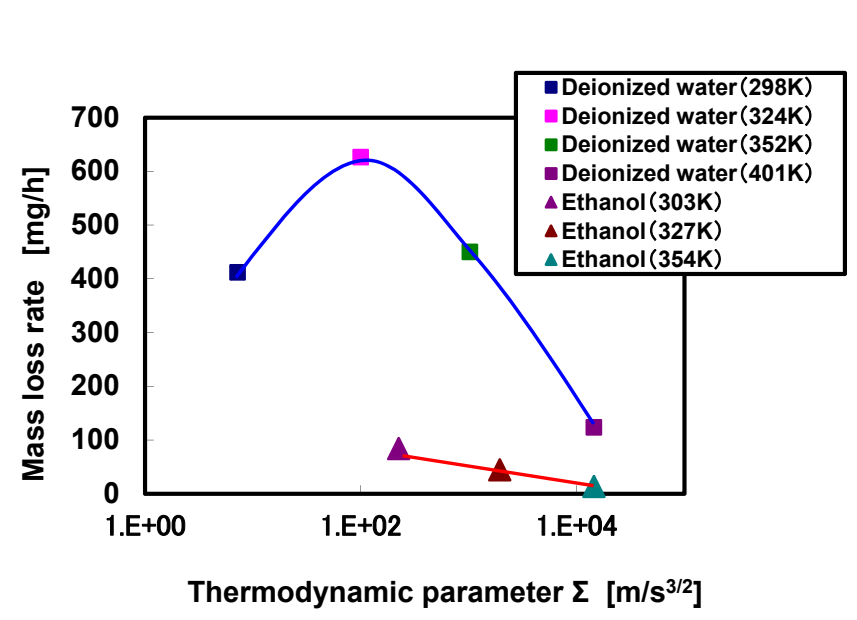

Fig. 7 Relation between mass loss and thermodynamic parameter $\Sigma$

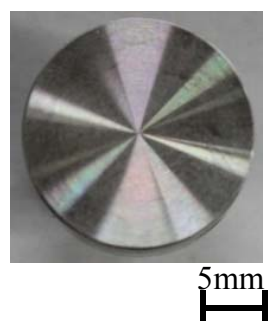

(a) Original surface

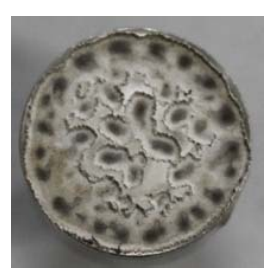

(e) Deionized water

$401 \mathrm{~K}, \quad 0.35 \mathrm{MPa}$

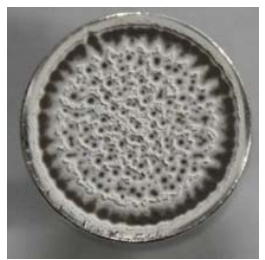

(b) Deionized water 298K, 0.1MPa

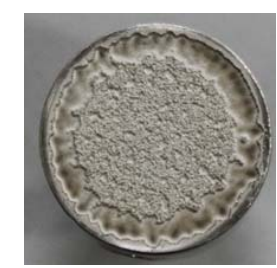

(f) Ethanol $303 \mathrm{~K}, \quad 0.1 \mathrm{MPa}$

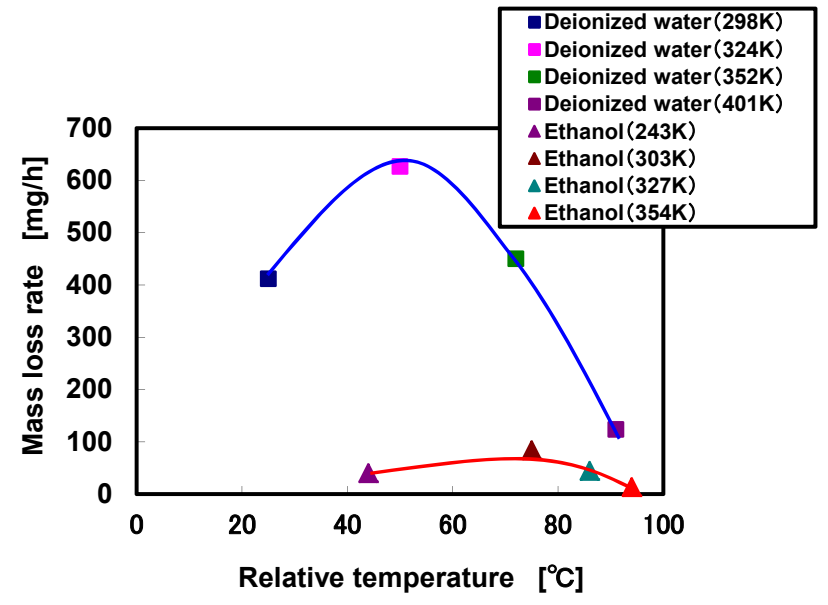

Fig. 8 Relation between mass loss and relative temperature

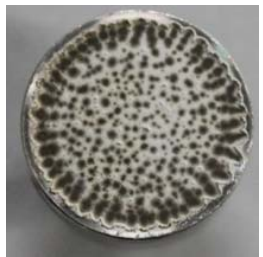

(c) Deionized water $324 \mathrm{~K}, \quad 0.11 \mathrm{MPa}$

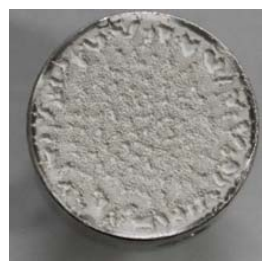

(g) Ethanol $327 \mathrm{~K}, \quad 0.11 \mathrm{MPa}$

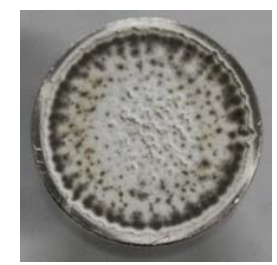

(d) Deionized water $352 \mathrm{~K}, \quad 0.14 \mathrm{MPa}$

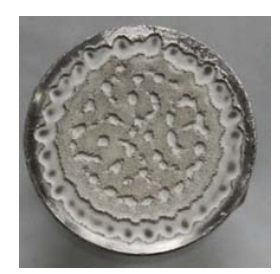

(h) Ethanol $354 \mathrm{~K}, \quad 0.19 \mathrm{MPa}$

Fig.9 Eroded surface of test specimens 


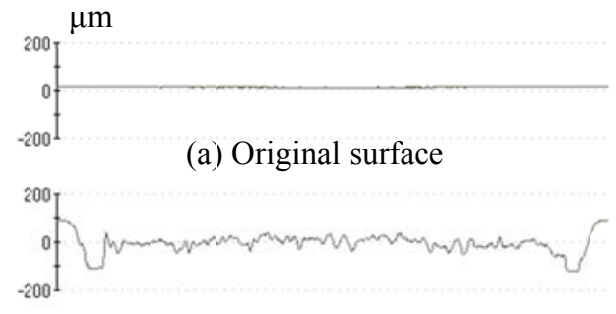

(b) $298 \mathrm{~K}, \quad 0.1 \mathrm{MPa} \quad 30 \mathrm{~min}$

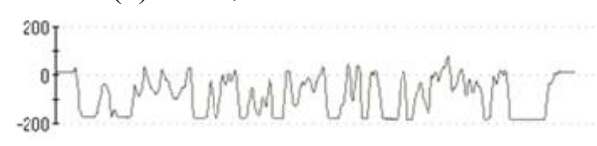

(c) $324 \mathrm{~K}, \quad 0.11 \mathrm{MPa} \quad 20 \mathrm{~min}$

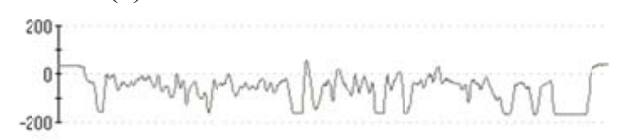

(d) $352 \mathrm{~K}, \quad 0.14 \mathrm{MPa} \quad 30 \mathrm{~min}$

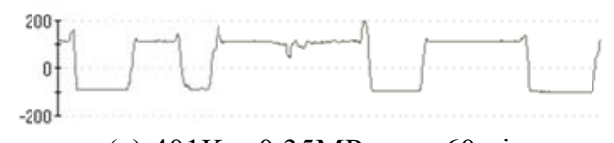

(e) $401 \mathrm{~K}, \quad 0.35 \mathrm{MPa} \quad 60 \mathrm{~min}$

Fig.10 Surface profile in deionaized water

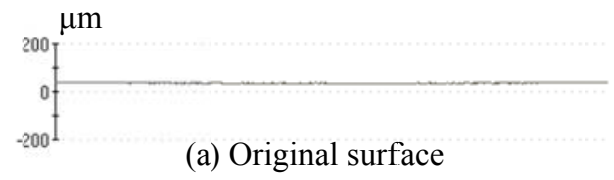

(a) Original surface

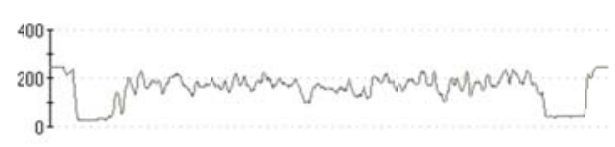

(b) $303 \mathrm{~K}, \quad 0.1 \mathrm{MPa} \quad 2 \mathrm{~h}$

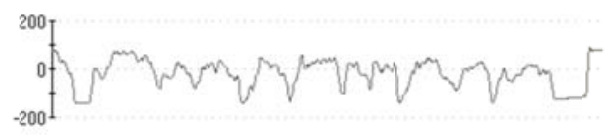

(c) $327 \mathrm{~K}, \quad 0.11 \mathrm{MPa} \quad 5 \mathrm{~h}$

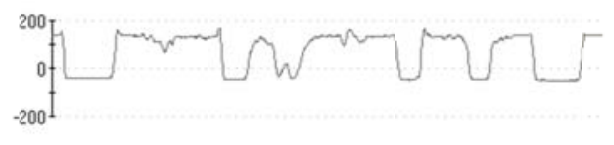

(d) $354 \mathrm{~K}, \quad 0.19 \mathrm{MPa} \quad 20 \mathrm{~h}$

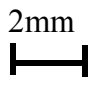

Fig.11 Surface profile in ethanol

力学的効果によって壊食速度が小さくなったものと考えられる．しかし， $\Sigma=1 \times 10^{2}$ 以下になると壊食速度が 小さくなり, 揚程低下点のキャビテーション係数の $\Sigma$ 依存性の報告 ${ }^{(8)}$ とは傾向が異なっている. そのため, 相対温度と壊食速度の関係で整理した．相対温度は次式で表される。

$$
\text { 相対温度 }=(\text { 試験温度 }- \text { 融点 }) /(\text { 沸点 }- \text { 融点 })
$$

この結果を図 8 に示す. 図 8 はこれまで報告されている結果 ${ }^{(17)}$ と類似した曲線になる。これまでの報告 ${ }^{(16)}$ と 同様に相対温度が約 $25^{\circ} \mathrm{C}$ なると，蒸気圧が低くなって気泡数が減少したためであると考えられる。

図 9 は試験前及び試験後の試験面の様子である. 処女面は滑らかであり, 凹凸は見られない. 試験後の試 験面は凹凸が激しく，壊食が端面付近で進んでいる．脱イオン水中での試験は，壊食速度が大きいため母材 の露出している箇所が多く見られる.エタノール中での試験は，脱イオン水中に比べると壊食は浅いが，端 面付近では母材が露出している箇所が見られる.

図 10 は, 脱イオン水中で温度と圧力を変化させた場合の表面形状を示したものである. 同程度の壊食量で 表面形状の違いを比較するため，いずれの図も壊食量は約 $150 \mathrm{mg}$ である. $298 \mathrm{~K} ， 0.1 \mathrm{MPa}$ の試験は端面付近 の壊食が大きく, 中心付近はほぼ同じ壊食深さで壊食が進んでいる。324K，0.11MPa の表面形状と 352K， 0.14MPa の表面形状は類似しており，298K，0.1MPa の表面形状に比べて壊食の大きい箇所と壊食の小さい箇 所が顕著に現れている，401K，0.35MPa の表面形状では，壊食の大きい箇所と壊食の小さい箇所がさらに顕 著になり, 壊食の進行が速い箇所では母材が露出し, 壊食の進行が遅い箇所はほとんど変化していない. 壊 食の生じた箇所から徐々に壊食が広がっている.

図 11 は, エタノール中で温度と圧力を変化させた場合の表面形状を示した図である.図 11 も図 10 と同様, 壊食量が約 $150 \mathrm{mg}$ の時の表面形状である. 303K，0.1MPa の試験は端面付近の壊食が大きく，中心付近は壊 食の進行にばらつきが見られる. 327K，0.11MPaの表面形状は，303K，0.1MPa の表面形状と類似しているが 中心付近の壊食のばらつきがより顕著である. $354 \mathrm{~K}, 0.19 \mathrm{MPa}$ の表面形状は, 脱イオン水中での $401 \mathrm{~K}, 0.35 \mathrm{MPa}$ の表面形状と同様に壊食の進行がはっきりと分かれている. 
以上より, 熱力学的パラメータ $\Sigma$ が $100 \mathrm{~m} / \mathrm{s}^{3 / 2}$ 以上になると熱力学的効果が現れて壊食が局所化されて壊食

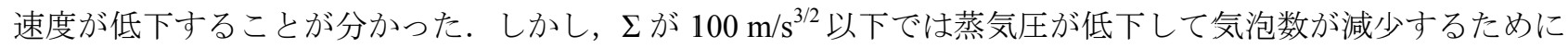
壊食速度は小さくなったものと考えられる。

\section{$3 \cdot 290 \mathrm{~K} ， 0.3 \mathrm{MPa}$ の LOX を基準にしたキャビテーション壊食試験}

298K，0.1MPa の脱イオン水を基準にした試験では，LOX 中での圧力の影響を考慮していないので，極低 温流体の壞食量を予測するには不十分であると考えられる。本節では，90K で実機に使用されている $0.3 \mathrm{MPa}$ の条件での LOX を基準にした. この時のキャビテーション数は 92.4 である. 熱力学的パラメータの值は前 節と同様にいずれの試験も 14500 である. 試験液, 試験条件を表 3 に示寸. 試験液にはへキサンを追加した. 本試験は，LOX 中での条件と同一になるように熱力学的パラメータ及びキャビテーション数を一致するよう に試験液の液温と加える圧力を調節した。そのため，壊食速度に影響を及ぼすのは，試験液の特性であり， 主に音響インピーダンスの違いが壊食速度に影響を及ぼすと考えられる。試験液の音響インピーダンスを表 4 に示す.

図 12 に累積質量減少量曲線を示す.いずれの曲線も明瞭な潜伏期は現れず，試験直後に最大速度期が現れ ている. 脱イオン水中での試験は, 試験開始 10 分間で $80 \mathrm{mg}$ ，その後は 10 分毎に約 $50 \mathrm{mg}$ 質量減少してほぼ

Table 3 Test conditions based on LOX at 90K

\begin{tabular}{|c|c|c|c|c|c|}
\hline $\begin{array}{c}\text { Test } \\
\text { liquid }\end{array}$ & $\begin{array}{c}\text { Temperature } \\
{[\mathrm{K}]}\end{array}$ & $\begin{array}{c}\text { Thermodynamic } \\
\text { parameter } \\
\Sigma\end{array}$ & $\begin{array}{c}\text { Test pressure } \\
{[\mathrm{MPa}]}\end{array}$ & $\begin{array}{c}\text { Saturated vapor } \\
\text { pressure } \\
{[\mathrm{MPa}]}\end{array}$ & $\begin{array}{c}\text { Cavitation } \\
\text { number }\end{array}$ \\
\hline $\begin{array}{c}\text { Liquid } \\
\text { oxygen }\end{array}$ & 90 & 14500 & 0.300 & 0.0994 & 92.4 \\
\hline $\begin{array}{c}\text { Deionized } \\
\text { water }\end{array}$ & 401 & 14500 & 0.418 & 0.2530 & 92.4 \\
\hline Ethanol & 354 & 14500 & 0.241 & 0.1120 & 92.4 \\
\hline Hexane & 343 & 14500 & 0.213 & 0.1050 & 92.4 \\
\hline
\end{tabular}

Table 4 Acoustic impedance of test liquid

\begin{tabular}{|c|c|c|c|}
\hline Test liquid & $\begin{array}{c}\text { Density of liquid } \\
{\left[\mathrm{kg} / \mathrm{m}^{3}\right]}\end{array}$ & $\begin{array}{c}\text { Sound } \\
\text { velocity } \\
{[\mathrm{m} / \mathrm{s}]}\end{array}$ & $\begin{array}{c}\text { Acoustic } \\
\text { impedance } \\
{\left[\mathrm{kg} /\left(\mathrm{m}^{2} \mathrm{~s}\right)\right]}\end{array}$ \\
\hline Liquid oxygen & 1142 & 906 & $1.03 \times 10^{6}$ \\
\hline $\begin{array}{c}\text { Deionized } \\
\text { water }\end{array}$ & 937 & 1508 & $1.41 \times 10^{6}$ \\
\hline Ethanol & 732 & 1000 & $0.73 \times 10^{6}$ \\
\hline Hexane & 612 & 868 & $0.53 \times 10^{6}$ \\
\hline
\end{tabular}

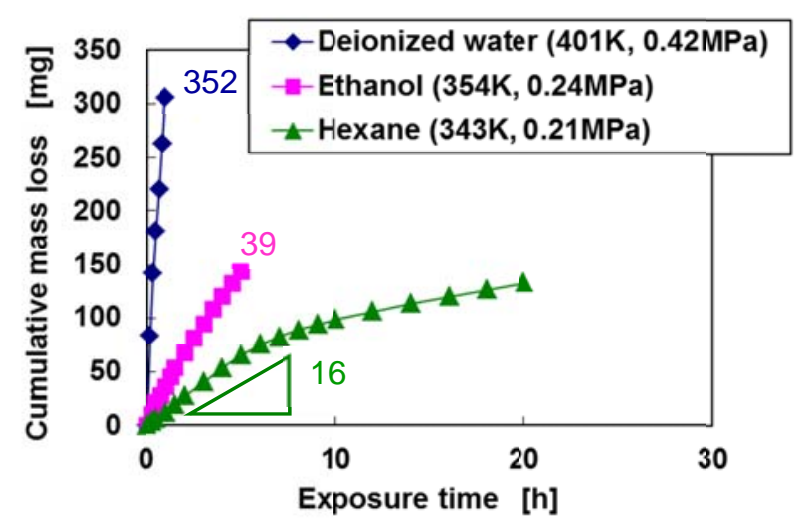

Fig. 12 Mass loss curves

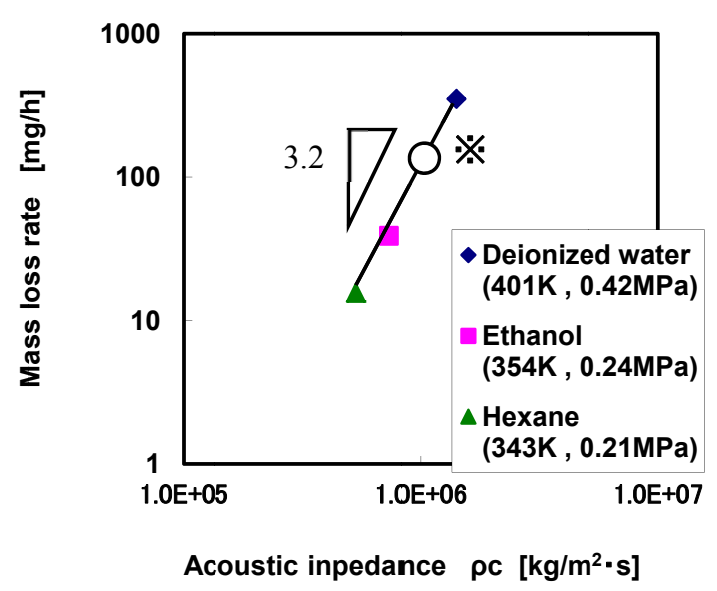

Fig. 13 Relation between mass loss rate and acoustic impedance 


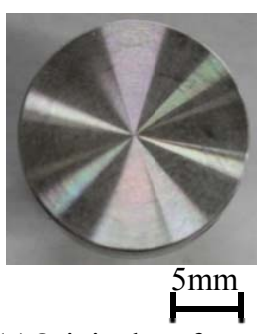

(a)Original surface

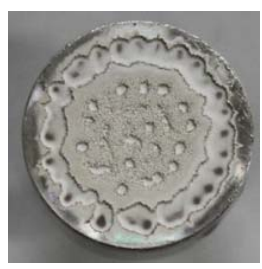

(c) Ethanol $354 \mathrm{~K}, 0.24 \mathrm{MPa}$

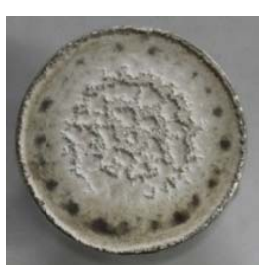

(b) Deionized water $401 \mathrm{~K}, \quad 0.42 \mathrm{MPa}$

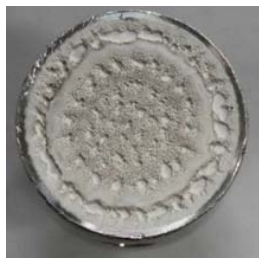

(d) Hexane $343 \mathrm{~K}, \quad 0.21 \mathrm{MPa}$

Fig. 14 Eroded surface of test specimens

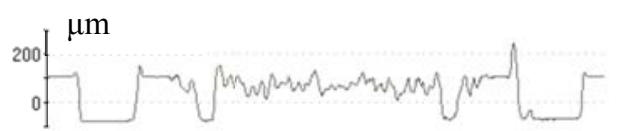

(a) Deionized water $401 \mathrm{~K}, 0.42 \mathrm{MPa} \quad 20 \mathrm{~min}$

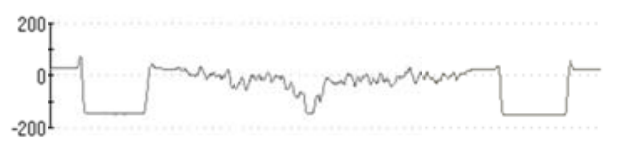

(b) ethanol $354 \mathrm{~K}, \quad 0.24 \mathrm{MPa} \quad 5 \mathrm{~h}$

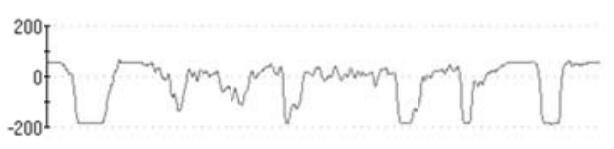

(c) Hexane $343 \mathrm{~K}, \quad 0.21 \mathrm{MPa} \quad 20 \mathrm{~h}$

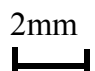

Fig. 15 Surface profile

直線的に壊食が進んでいる。エタノール中での試験は，イオン交換中での試験よりも壊食速度が小さい。試 験開始 30 分までは壊食速度が約 $40 \mathrm{mg} / \mathrm{h}$ で壊食が進むが，壊食速度は徐々に小さくなり，2 時間後には約 $30 \mathrm{mg} / \mathrm{h}, 5$ 時間後には約 $20 \mathrm{mg} / \mathrm{h}$ となっている. ヘキサン中での試験は, エタノール中での試験よりも壊食速 度が小さい. 試験開始 5 時間は壊食速度が約 $12 \mathrm{mg} / \mathrm{h}$ で壊食が進むが，その後，壊食速度は徐々に小さくなり 10 時間後には約 $5 \mathrm{mg} / \mathrm{h}, 20$ 時間後には約 $3 \mathrm{mg} / \mathrm{h}$ となっている. 表 4 の音響インピーダンスと図 12 の試験結 果を比較すると，音響インピーダンスが大きいほど壊食速度が大きくなることが分かる. 図中の数字は最大 速度期の勾配を示している.

困 13 は，各種試験液の壊食速度と音響インピーダンスの関係を示したものである。3 種類の試験液でキャ ビテーション試験を行った結果，図 13 のように両対数紙上で直線関係が得られる。この直線の傾きは 3.2 で あり，Wilson ら ${ }^{(18)}$ とるる質量減少量と音響インピーダンスの関係の傾き 2.8 と類似している。そのため，キ ヤビテーション発生状況を模擬した場合, 図の直線でLOX 中での壊食速度を推測することができると考えら れる，音響ピーダンスを基にLOX 中での磁わい振動試験を行った場合の結果を推測した点が，図 13 の※印 である。この結果より LOX 中で磁わい振動試験を行った場合，キャビテーション壊食が発生する可能性があ る。また，この結果より熱力学的パラメータ及びキャビテーション数に加え，音響インピーダンスを考慮す ることにより壊食速度を整理できると考えられる。

図 14 は試験前及び 3 種類の試験液での壊食試験後の試験面の様子である. 処女面は，滑らかであり凹凸は ない. 試験後の試験面はいずれも端面付近の壊食が大きく，中心付近では壊食の大きい箇所と小さい箇所が 混在し凸凹が見られる。困 15 は，3 種類の試験液で試験を行った時の表面形状であり，いずれの図も壊 食量は約 $150 \mathrm{mg}$ である.いずれの試験面形状も大差は認められないが，ヘキサン中では中央部に深い壊 食痕が現れる特徴がある。

以上より，熱力学的パラメータ及びキャビテーション数が等しい場合には，各種液体の音響インピーダン スにより壊食速度を評価できると考えられる。

\section{4. 結言}

銀めっき材料のキャビテーション壊食試験を行い，試験結果の比較検討を行った結果，以下の結論が得ら れた。

1. $303 \mathrm{~K}$ から $403 \mathrm{~K}$ までの温度範囲では銀めっき材料の硬さは変化しない. そのため, 壊食速度の温度 依存性は，材料特性によるものではなく，液体特性の変化によるものである. 
2. 脱イオン水中やエタノール中の $303 \mathrm{~K}$ から $403 \mathrm{~K}$ の変化は, 熱力学的パラメータ $\Sigma と し て は ~ 10 〜 2.0 \times 10^{5}$ $\mathrm{m} / \mathrm{s}^{3 / 2}$ に対応寸る. 熱力学的パラメータ $\Sigma$ が $100 \mathrm{~m} / \mathrm{s}^{3 / 2}$ 以上になると熱力学的効果が現れ壊食が局所化さ れて壊食速度が低下寸る.しかし， $\Sigma$ が $100 \mathrm{~m} / \mathrm{s}^{3 / 2}$ 以下では蒸気圧が低下して発生する気泡数が減少す るために壊食速度は小さくなる.

3. 各種液体中の壊食速度は, 熱力学的パラメータ及びキャビテーション数が等しい場合には, 液体 の音響インピーダンスにより評価できる.

\section{謝 辞}

本研究においてご協力を頂きましたJAXAの川崎聡氏に謝意を表します.

\section{参考文献}

(1) 上條謙二郎，山田仁，“ロケットポンプの液体水素インデューサ”, ターボ機械, Vol.35, No.9(2007), pp.47-52.

(2) 山田仁, 内海政春, “ロケット用ターボポンプの流体関連振動事例”, ターボ機械, Vol.36, No.2(2008), pp.3-9.

(3) 内海政春, 山田仁，上條謙二郎，“キャビティとインデューサ羽根の干涉評価とその適応事例”, ターボ機械, Vol.38, No.6(2010), pp.327-333.

(4) 菊池正孝, 長谷川敏, 野坂正隆, 陣内毅, “液体酸素, 液体窒素中における銀/硬質皮膜の摩擦摩耗特性”, (社)日 本トライボロジー学会トライボロジー会議予稿集, 金沢(1994-10), pp.579-582.

(5) 野坂正隆, “低温環境下におけるトライボロジー”, トライボロジスト, Vol.52, No.11(2007), pp.759-764.

（6）服部修次, 籠谷勇, 川崎聡, 河野真一郎, “低温環境下における銀めっき材のキャビテーション壞食”, 日本機械 学会論文集 A 編, Vol.77, No.775 (2011), pp.438-447.

(7) Brennen, C., "The Dynamic Behavior and Compliance of a Stream of Cavitating Bubbles", Transaction of the ASME, (1973), pp.533-541.

（8）ターボ機械協会編，ポンプのキャビテーション損傷の予測と評価，ターボ機械協会指針 TSJ G 001 (2011), pp.63-64, ターボ機械協会.

(9) 渡邊聡, 古川明徳, “キャビテーションの熱力学的効果とその理論解析”, ターボ機械, Vol.36, No.3 (2006), pp.26-33.

(10) ソフトウェア「Reference fluid thermodynamic and transport properties (REFPROP)」, データベース「National Institute of Standards and Technology, "Nist standard reference database 23, Version 8.0"」

(11) 株式会社ミツトヨ, “カタログ No.17001硬さ試験機総合”, 株式会社ミットヨ, http://www.mitutoyo.co.jp/support/service/catalog/index05.html (参照日 2010 年 12 月 12 日)

(12) Gross, L.A., "An Experimental Investigation of Two-phase Liquid Oxygen Pumping”, NASA TN D-7451, (1973).

(13) Yoshida, Y., Kikuta, K., Hasegawa, S., Shimagaki, M., and Tokumasu, T., "Thermodynamic Effect on a Cavitating Inducer in Liquid Nitrogen”, Transaction of the ASME, Journal of Fluid Engineering, Vol.129, (2007), pp.273-278.

(14) Yoshida, Y., Nanri, H., Kikuta, K., Kazami, Y., Iga, Y., and Ikohagi, T., "Thermodynamic Effect on Subsynchronous Rotating Cavitation and Surge Mode Oscillation in a Space Inducer", Transaction of the ASME, Journal of Fluid Engineering, Vol.133, (2011), pp.06130-1-06130-7.

(15) 菊田研吾, 吉田義樹, 橋本知之, 南里秀明, 水野勉, 四宮教行, “インデューサに発生するキャビテーションの 熱力学的効果に与える回転数の影響”, 日本機械学会論文集 B 編, Vol.76, No.772 (2010), pp.102-110.

(16) Franc, J.P., Rebattet, C., and Coulon, A., "An Experimental Investigation of Thermal Effects in a Cavitating Inducer”, Transaction of the ASME, Journal of Fluid Engineering, Vol.126, No.5 (2004), pp.716-723.

(17) 服部修次, 後藤佑規, 福山岳樹, 八木良憲, 村瀬道雄, “キャビテーション噴流法による壊食に及ぼす液温の影 響”, 日本機械学会論文集 A 編, Vol.71, No.707 (2005), pp.89-95.

(18) Wilson, R.W., and Graham, R., "Cavitation of Surfaces in Contact with Lubricants", Conf. Lubrication and Wear, IME, London (1957), pp.707-712. 